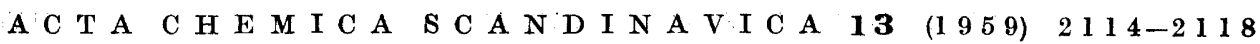

\title{
Polarographic Determination of Hydroxylamine, alone and in Comparison with Hydroxamic Acid
}

\author{
TH. ØSTERUD and M L DA PRYTZ
}

Universitetets Farmasфytiske Institutt, Blindern-Oslo, Norway

\begin{abstract}
Hydroxylamine has been polarographically reduced in ethanolwater solutions of tetraethylammonium iodide. The $\mathrm{pH}$ of the supporting electrolyte was increased by addition of small amounts of tetraethylammonium hydroxide.
\end{abstract}

The $\mathrm{pH}$ of the tetraethylammonium iodide solution before addition of $\mathrm{nydr}$ 1 oxide was 5.4. In this medium the hydroxylamine gave three distinct waves. The first wave which had $E_{1 / 2}=-1.44$ vs S.C.E. (-1.11 vs $\mathrm{Hg}$ ), disappeared as soon as $\mathrm{pH}$ was raised, i.e. the buffer-capacity was increased. At $\mathrm{pH}=5.6$ this wave had disappeared and did not reappear on further increase of $\mathrm{pH}$. In the $\mathrm{pH}$-interval 5.6 to 13.3 the curves showed two well defined waves, the first, which had $E_{1 / 2}=-2.1$ vs S.C.E. $(-1.74 v s \mathrm{Hg})$, being the highest. At $\mathrm{pH}=11$ it started decreasing, while the height of the second wave having $E_{1 / 2}=-2.35$ vs S.C.E. $(-1.9$ vs $\mathrm{Hg}$ ) kept a constant low height. At $\mathrm{pH}$ greater than 14 the first wave seemed to coalesce with the second wave, which in this strong alkaline medium suddenly reaches an appreciable height.

The measurements of hydroxamic acid were a corroboration of earlier investigations, as we wanted to test eventual differences as regards the form of the curves and the values of the half wave potentials.

The first wave for the hydroxamic acid shows a half wave potential about $0.2 \mathrm{~V}$ lower than for the hydroxylamine, and the second wave about $0.1 \mathrm{~V}$ higher. The form of the curves did not differ noticeably.

Inasmuch as hydroxylamine is unstable in alkaline medium we controlled its deterioration at $\mathrm{pH}=11.7$ to 12.3 by taking a series of diagrams at fixed intervals of half an hour. Already after half an hour a decrease of wave height was unmistakable, and after an hour and a half the wave height had reached a low value which was controlled the next day. It had not changed appreciably over night. Next the reaction velocity was increased by raising the temperature to $60^{\circ} \mathrm{C}$ and $100^{\circ}$, respectively. A $60^{\circ} \mathrm{C}$ a wave height of about $1 / 3$ of the original was reached after $30 \mathrm{~min}$, and at $100^{\circ} \mathrm{C}$ even after a few minutes. 
The time effect on solutions of acethydroxamic acid and on solutions of propiohydroxamic acid was also tested at $\mathrm{pH}=11$ to 11.7 ; but the polarographic waves of these acids were not influenced by time. The effect of raising the temperature was also tested. No differences in the curves were observed.

These results seem to indicate that eventual hydroxylamine waves need not interfere with polarographic waves of aliphatic hydroxamic acids if the hydroxylamine is decomposed by heating in alkaline solution ( $\mathrm{pH} 12$ to 14) before the polarograms are taken.

As our ultimate aim is to determine aliphatic esters polarographically after transformation into hydroxamic acids it is of interest to see if these acids give curves that differ from those of hydroxylamine, inasmuch as the reaction mixture may contain an excess of hydroxylamine.

Some mixtures of hydroxylamine and hydroxamic acid were also polarographed, and the effect of time and heating was tested. The $\mathrm{pH}$ was 10 and did not change appreciably during the experiments. The readings were taken at room temperature.

We presume to have established by these experiments that hydroxamic acid may be polarographically determined in a solution containing hydroxylamine, inasmuch as the latter may be destructed by heating, whereas the former is not affected.

\section{EXPERIMENTAL}

A recording polarograph from Radiometer, Copenhagen, was employed. As working cell was used an arrangement of Nife cells in series with a rectifier. The usual precautions against oxygen were taken. For investigation of the temperature influence a water bath was used.

The tetraethylammonium iodide for the supporting electrolyte was delivered by Merck, Darmstadt. It had to be recrystallized repeatedly, as it otherwise was apt to give quite

Table 1. Polarographic waves of hydroxylamine and of acethydroxamic acid in relation to $\mathrm{pH}$. Measured at $1 /$ sens. $=50 ; c_{\text {aceth. }}=7 \times 10^{-3} \mathrm{M} ; c_{\text {hydrox. }}=$ about $10^{-3} \mathrm{M}$.

a. Mercury anode

b. S.C.E. anode

\begin{tabular}{|c|c|c|c|c|c|c|c|c|c|c|c|}
\hline \multicolumn{3}{|c|}{ Hydroxylamine } & \multicolumn{3}{|c|}{$\begin{array}{l}\text { Acethydroxamic } \\
\text { acid }\end{array}$} & \multicolumn{3}{|c|}{ Hydroxylamine } & \multicolumn{3}{|c|}{$\begin{array}{l}\text { Acethydroxamic } \\
\text { acid }\end{array}$} \\
\hline $\mathrm{pH}$ & $E_{1 / 2}^{1}$ & $E_{1 / 2}^{2}$ & $\mathrm{pH}$ & $E_{1 / 2}^{1}$ & $E_{1 / 2}$ & $\mathrm{pH}$ & $E_{1 / 2}^{1}$ & $E_{1 / 2}^{2}$ & $\mathrm{pH}$ & $E_{1 / 2}^{1}$ & $E_{1 / 2}^{2}$ \\
\hline $\begin{array}{r}5.4 \\
5.6 \\
5.8 \\
7.2 \\
7.7 \\
8.8 \\
11.0 \\
13.3\end{array}$ & $\begin{array}{c}(1.11) \\
1.52 \\
1.74 \\
1.76 \\
1.80 \\
1.76 \\
1.74 \\
1.73 \\
1.65\end{array}$ & $\begin{array}{l}1.90 \\
1.89 \\
1.92 \\
1.96 \\
1.92 \\
1.89 \\
1.87 \\
1.78\end{array}$ & $\begin{array}{r}8.8 \\
11.0 \\
13.3\end{array}$ & $\begin{array}{l}1.59 \\
1.58 \\
1.54\end{array}$ & $\begin{array}{r}1.99 \\
2.04\end{array}$ & $\begin{array}{l}5.4 \\
5.6 \\
\\
6.8\end{array}$ & $\begin{array}{c}(1.44) \\
2.07 \\
2.03 \\
\\
2.06\end{array}$ & $\begin{array}{l}2.35 \\
2.31 \\
\\
2.34\end{array}$ & $\begin{array}{l}10.7 \\
12.5 \\
13\end{array}$ & $\begin{array}{c}\text { None } \\
" \\
"\end{array}$ & $\begin{array}{l}2.54 \\
2.46 \\
2.47\end{array}$ \\
\hline
\end{tabular}

Acta Chem. Scand. 13 (1959) No. 10 


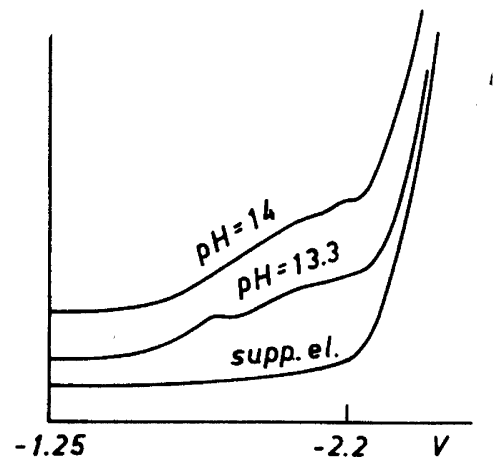

Fig. 1. a. Electroreduction of hydroxylamine at $\mathrm{pH} 13.3$ and 14.

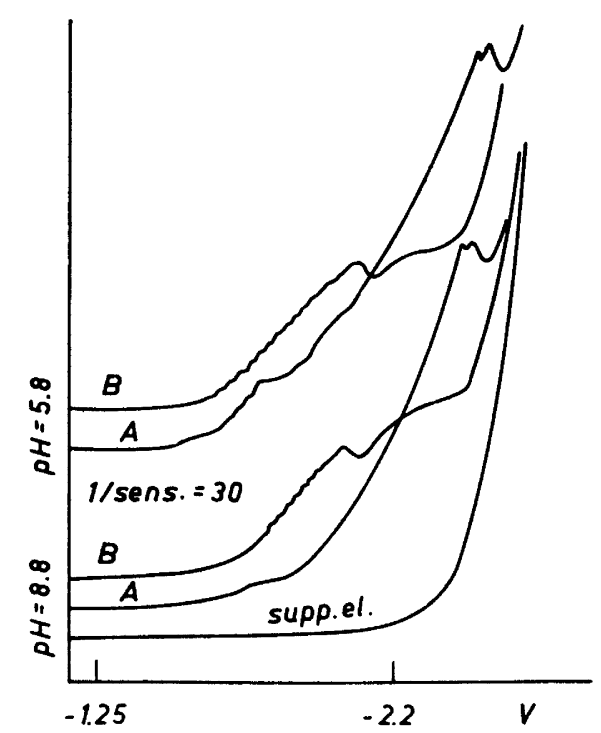

b. Electroreduction of acethydroxamic acid, $\mathrm{A}$, and of hydroxylamine, $\mathrm{B}$, at $\mathrm{pH}$ 5.8 and $8.81 /$ sens. $=30$.

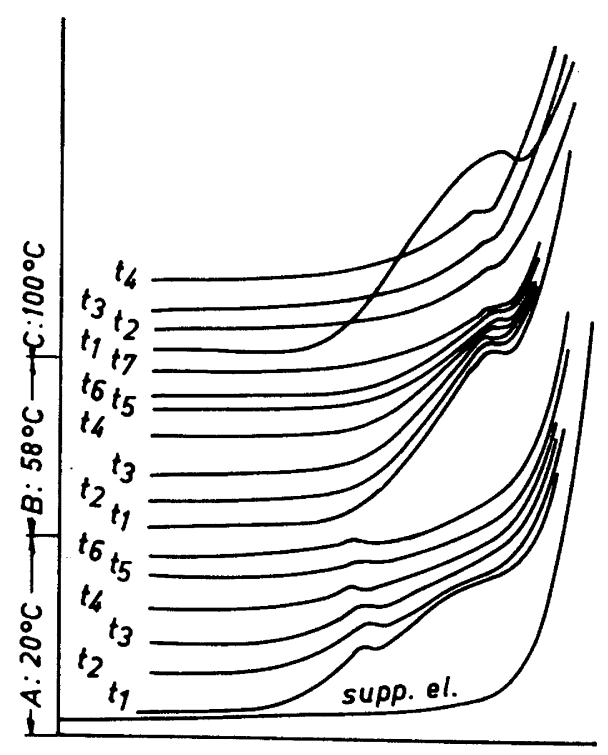

Fig. 2. Reduction of wave height of hydroxylamine with time at different temperatures:

A. at $20^{\circ} \mathrm{C} ; t_{1}=0 ; t_{8}=1 / 2$ hour; $t_{3}=1$ hour; $t_{4}=11 / 2$ hour; $t_{5}=2$ hours; $t_{6}=26$ hours

B. at $58^{\circ} \mathrm{C} ; t_{1}=0 ; t_{2}=3$ min.; $t_{3}=5$ min.; $t_{\mathrm{a}}=12 \mathrm{~min}$.; $t_{\mathrm{s}}=15 \mathrm{~min}$.; $t_{\mathrm{b}}=18 \mathrm{~min}$.; $t_{7}=30 \mathrm{~min}$.

C. at $100^{\circ} \mathrm{C} ; t_{1}=0 ; t_{2}=15 \mathrm{~min} ; t_{3}=10 \mathrm{~min}$.; $t_{4}=20 \mathrm{~min}$. 


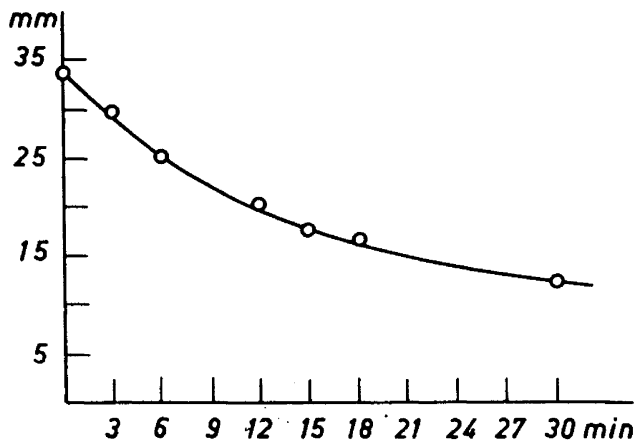

Fig. 3. Destruction of hydroxylamine at $58^{\circ} \mathrm{C} . \mathrm{pH}=12.3$ Wave heights as ordinates. Lapse of time as abscissae.

irrelevant maxima and minima. $50 \%$ alcohol proved to be the best solvent for recrystallization. For our previous investigation we used a tetraethylammonium iodide from the British Drughouses; but unfortunately we had very little salt left. Tetrabutylammonium iodide from A. Frederick Smith, Columbus, Ohio, gave straight and good curves without any recrystallization.

As a maximum depressor was used tylose, about $0.005 \%$.

\section{RESULTS}

The polarographic curves for hydroxylamine showed two waves similar to those we had earlier found for hydroxamic acid ${ }^{1}$, but with other values for the half wave potentials. These are given for both hydroxylamine and acethydroxamic acid in Table 1.

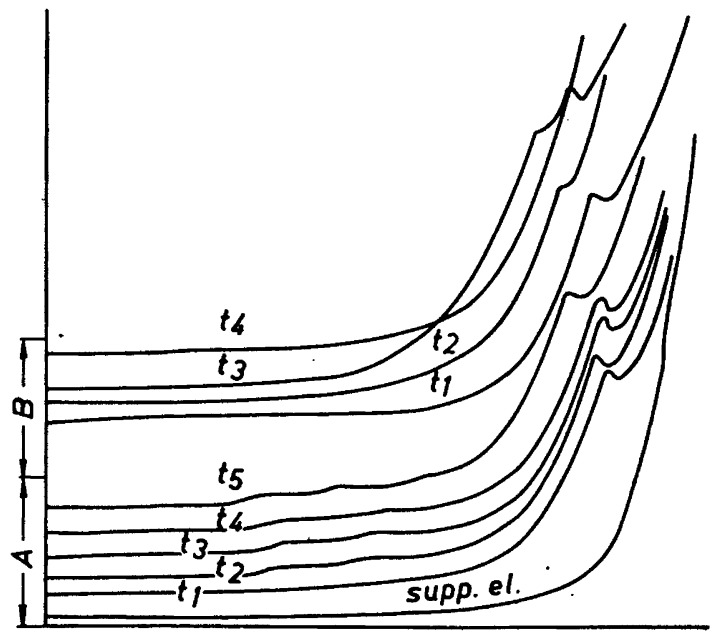

Fig. 4. Electroreduction of acethydroxamic acid at $20^{\circ} \mathrm{C}$ and at $100^{\circ} \mathrm{C}$.

A. at $20^{\circ} \mathrm{C} ; t_{1}=0 ; t_{2}=1 / 2$ hour; $t_{3}=1$ hour; $t_{4}=11 / 2$ hour; $t_{5}=50$ hours.

B. at $100^{\circ} \mathrm{C} ; t_{1}=0 ; t_{2}=20 \mathrm{~min}$; $t_{3}=50 \mathrm{~min}$; $t_{4}$ after a lapse of 24 hours.

Acta Chem. Scand. 13 (1959) No. 10 
Some of the curves are given in Fig. $1 \mathrm{a}$ and $\mathrm{b}$.

It appears from Fig. 1 a that the hydroxylamine waves coalesce at $\mathrm{pH}=14$. The first wave can still be seen at $\mathrm{pH}=13.3$, but at $\mathrm{pH}=14$ it has disappeared and the second wave has increased highly.

As regards the reduction of the hydroxylamine-waves with time and rise of temperature, Fig. 2 shows that at $20^{\circ} \mathrm{C}$ the wave height decreases appreciably during one hour and a half, while at $60^{\circ} \mathrm{C}$ half an hour is sufficient for a corresponding decrease, and at $100^{\circ} \mathrm{C}$ even a very short time will be enough. The decomposition of hydroxylamine with time at $60^{\circ} \mathrm{C}$ is shown in Fig. 3 .

An inquiry into an eventual time- and temperature-effect for acethydroxamic acid and propiohydroxamic acid was also made. As will be seen from Fig. 4, the polarographic curves remained unaltered with time, even though the temperature was raised.

Mixtures of hydroxylamine and hydroxamic acid were also polarographed; but the polarograms brought no new information.

\section{DISCUSSION}

For the hydroxylamine as well as for hydroxamic acids we found that in alkaline solutions (at corresponding $\mathrm{pH}$-intervals) they gave polarographic curves with two distinct waves. The half wave potentials for the hydroxylamine waves lay between those for acethydroxamic acid. At high $\mathrm{pH}$ values the hydroxylamine waves seemed to coalesce. The result was a single, rather high wave. A corresponding effect was not found for hydroxamic acids.

On the polarographic waves for hydroxamic acid no time effect was observed even if the test solutions were left standing till next day. The polarographic waves for hydroxylamine in alkaline solutions, on the other hand, decreased perceptibly if the polarographic determination was delayed. Heating accelerated the decrease greatly.

One may conclude as a consequence of these results that esters transformed to hydroxamic acids may be determined polarographically even if the reaction mixture contains some excess of hydroxylamine. All that needs to be done is to heat the mixture on a water bath for a short time before the curves are taken at room temperature.

The authors are indebted to Bjørn Bergmann-Paulsen for the recording of the polarograms.

\section{REFERENCE}

1. Prytz, M. and Østerud, Th. Acta Chem. Scand. 11 (1957) 1530.

Received June 6, 1959. 